University of Nebraska - Lincoln

DigitalCommons@University of Nebraska - Lincoln

Faculty Publications from the Harold W. Manter Laboratory of Parasitology

4-1985

\title{
Eimeria from Bats of the World: A New Species in Tomopeas ravus from Peru
}

Donald W. Duszynski

University of New Mexico, eimeria@unm.edu

Linda J. Barkley

Louisiana State University

Follow this and additional works at: https://digitalcommons.unl.edu/parasitologyfacpubs

Part of the Parasitology Commons

Duszynski, Donald W. and Barkley, Linda J., "Eimeria from Bats of the World: A New Species in Tomopeas ravus from Peru" (1985). Faculty Publications from the Harold W. Manter Laboratory of Parasitology. 162. https://digitalcommons.unl.edu/parasitologyfacpubs/162

This Article is brought to you for free and open access by the Parasitology, Harold W. Manter Laboratory of at DigitalCommons@University of Nebraska - Lincoln. It has been accepted for inclusion in Faculty Publications from the Harold W. Manter Laboratory of Parasitology by an authorized administrator of DigitalCommons@University of Nebraska - Lincoln. 


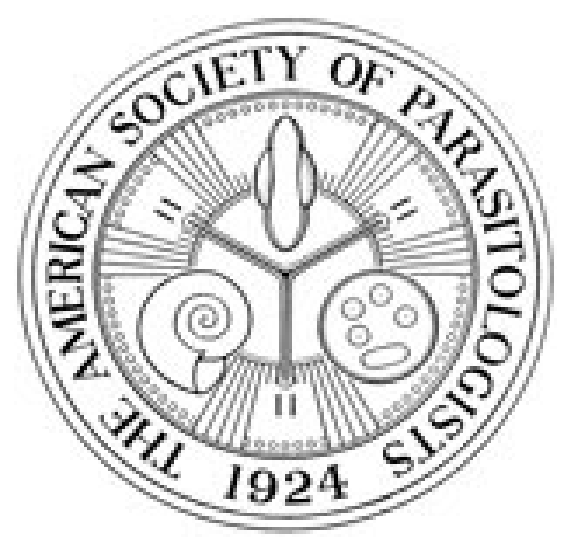

Eimeria from Bats of the World: A New Species in Tomopeas ravus from Peru Author(s): Donald W. Duszynski and Linda J. Barkley

Source: The Journal of Parasitology, Vol. 71, No. 2 (Apr., 1985), pp. 204-208

Published by: The American Society of Parasitologists

Stable URL: http://www.jstor.org/stable/3281903

Accessed: 21/04/2010 01:01

Your use of the JSTOR archive indicates your acceptance of JSTOR's Terms and Conditions of Use, available at http://www.jstor.org/page/info/about/policies/terms.jsp. JSTOR's Terms and Conditions of Use provides, in part, that unless you have obtained prior permission, you may not download an entire issue of a journal or multiple copies of articles, and you may use content in the JSTOR archive only for your personal, non-commercial use.

Please contact the publisher regarding any further use of this work. Publisher contact information may be obtained at http://www.jstor.org/action/showPublisher?publisherCode=asp.

Each copy of any part of a JSTOR transmission must contain the same copyright notice that appears on the screen or printed page of such transmission.

JSTOR is a not-for-profit service that helps scholars, researchers, and students discover, use, and build upon a wide range of content in a trusted digital archive. We use information technology and tools to increase productivity and facilitate new forms of scholarship. For more information about JSTOR, please contact support@jstor.org.

The American Society of Parasitologists is collaborating with JSTOR to digitize, preserve and extend access to The Journal of Parasitology. 


\title{
EIMERIA FROM BATS OF THE WORLD: A NEW SPECIES IN TOMOPEAS RAVUS FROM PERU
}

\author{
Donald W. Duszynski and Linda J. Barkley* \\ Department of Biology, The University of New Mexico, Albuquerque, New Mexico 87131
}

\begin{abstract}
Two of $17(12 \%)$ crevice bats, Tomopeas ravus (Chiroptera: Vespertilionidae), from Peru had coccidian oocysts in their feces when examined. Sporulated oocysts of Eimeria tomopea $\mathrm{n}$. sp. are ellipsoid to subspheroid, $30.6 \times 24.6(26-34 \times 20-28) \mu \mathrm{m}$ with ovoid sporocysts $13.9 \times 9.0(12-15 \times 8-10) \mu \mathrm{m}$. A micropyle and substieda body are absent, but polar bodies, oocyst and sporocyst residua, and small, indistinct Stieda bodies are present. The oocyst wall is thick, $\cong 1.5 \mu \mathrm{m}$ and consists of 2 layers, the outermost being rough and mammillated. This is only the 13 th eimerian to be described from bats worldwide. The currently recognized species of Eimeria are listed, and a possible New World-Old World phyletic split within the genus is described.
\end{abstract}

Tomopeas ravus is a very small $(3 \mathrm{~g})$, insectivorous bat known only from the arid and semiarid coastal region of Peru. In June and July 1981, one of us (LJB) collected 17 specimens as part of a study to determine the systematic relationships and natural history of this rare Peruvian mammal. Two of the bats were infected with an eimerian (Protozoa, Eimeriidae) which we describe here.

\section{MATERIALS AND METHODS}

Hosts were killed in the field a few hours after being removed from rock crevices by hand. All procedures for removing intestines, preserving fecal material, and processing, measuring and photographing oocysts were described earlier (Duszynski et al., 1982; Stout and Duszynski, 1983). All measurements are in $\mu \mathrm{m}$ with means given in parentheses following the ranges.

\section{RESULTS}

Two of 17 (12\%) specimens of Tomopeas ravus from Peru had large numbers of oocysts in their feces, and there is no doubt these represent a new species of coccidia which we describe below.

Received 13 August 1984; revised 15 October 1984; accepted 23 October 1984.

* Address: Museum of Natural Science and Department of Zoology and Physiology, Louisiana State University, Baton Rouge, Louisiana 70803.

\section{DESCRIPTION \\ Eimeria tomopea n. sp. \\ (Figs. 1-12)}

Oocyst wall of uniform thickness $\cong 1.5$ wide, consisting of 2 layers: outer layer yellowish, mammillated (Fig. 4), $\cong 2 / 3$ of total thickness; inner layer colorless, smooth; micropyle absent; polar body present (Fig. 2); oocyst residuum variable from a spheroid, homogeneous, lipid-like body $\cong 5$ (Figs. 1, 5), to multiple bodies (Fig. 6), to a coarse, granular sphere (Figs. 3, 7); sometimes there is a membrane-like structure associated with the lipid-like sphere (Figs. 1, 5); sporulated oocysts $(n=100)$ ellipsoid (Figs. 1,2$)$ to subspheroid (Fig. 3), 26-34 × 20-28 (30.6 × 24.6) with L:W ratio 1.16-1.35 (1.24); sporocysts ovoid (Figs. 8-11), 12$15 \times 8-10(13.9 \times 9.0)$ with $\mathrm{L}: \mathrm{W}$ ratio $1.38-1.80(1.54)$; substieda body absent; Stieda body small, not easily seen by brightfield microscopy unless sporocysts are freed from oocyst (cf. Figs. 1-3, 8, 10); even then, Stieda body is seen to better advantage with Nomarski interference contrast (NIC) microscopy (Figs. 9, 11); sporocyst residuum present as large scattered granules obscuring sporozoites (Figs. 1, 12); sporozoites with 1, large, posterior refractile body (Figs. 1, 8-12).

\section{TAXONOMIC SUMMARY}

Diagnosis: Of the 12 valid eimerians previously described from bats (Table I), only E. eumopos described from Eumops trumbulli from Colombia (South America) resembles Eimeria tomopea. The sporulated oocysts of E. tomopea differ from those of E. eumopos, however, by being smaller $(31 \times 25$ vs. $35 \times 28)$, by having a distinct oocyst residuum that $E$. eumopos lacks, by having larger sporocysts $(14 \times 9$ vs. $12 \times 5)$ with a large, granular residuum, and by having a Stieba body that is indistinct.

FIGURES 1-11. Photomicrographs of sporulated oocysts (1-7) and sporocysts (8-11) of Eimeria tomopea sp. n. $\times 1,815$. 1. Oocyst in optical cross-section; note oocyst residuum $\left({ }^{*}\right)$ and associated membrane-like structure (arrow); 2. A second sporulated oocyst showing polar body (arrow); 3. Subspheroid morph with granular oocyst residuum (*); 4. Mammillated surface of oocyst wall (NIC); 5-7. Sporulated oocysts showing variation in oocyst residuum (arrows); 8-11. Sporocysts seen with brightfield $(8,10)$ and NIC $(9,11)$; note the small Stieda body seen best with NIC optics (arrows). 


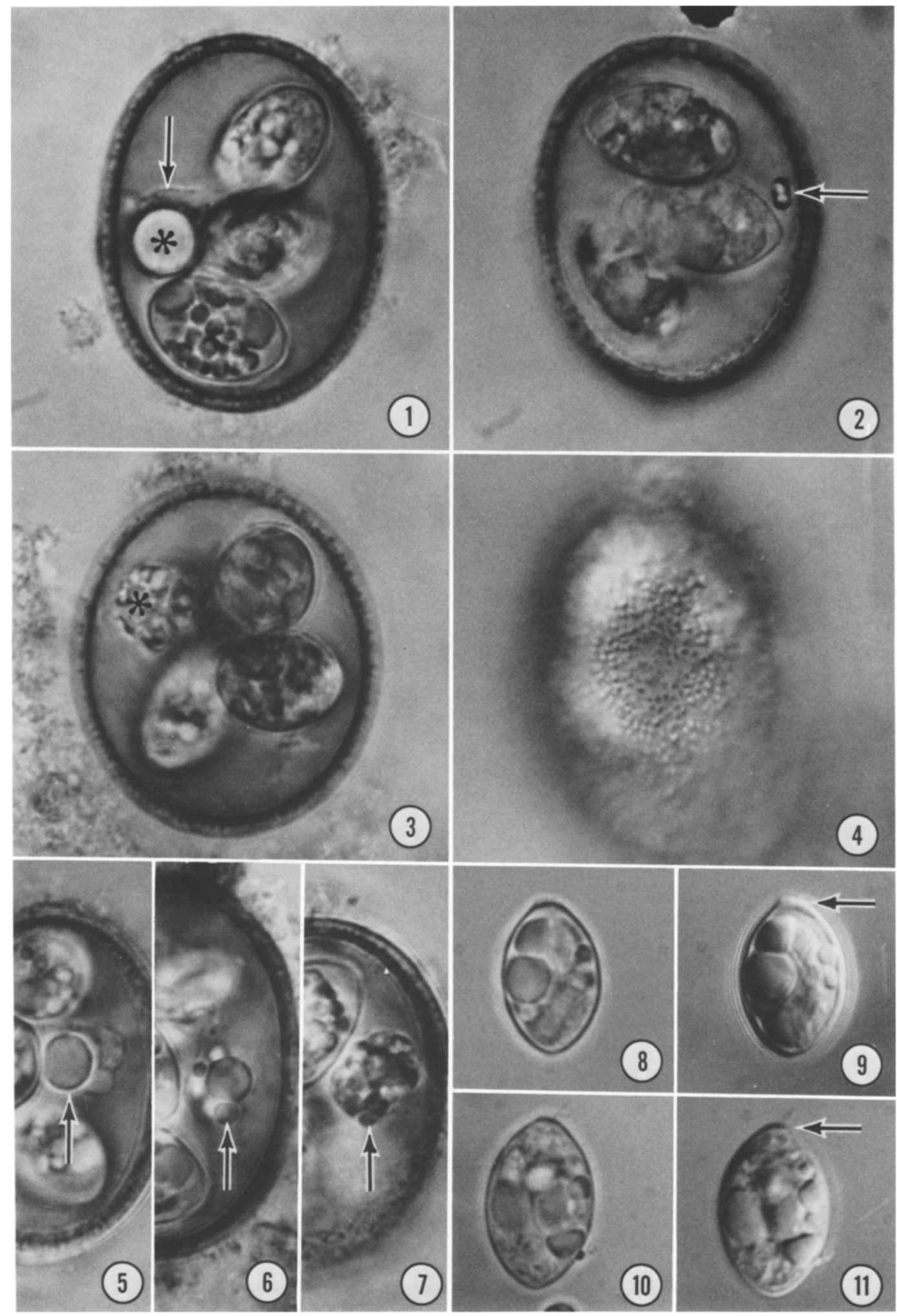




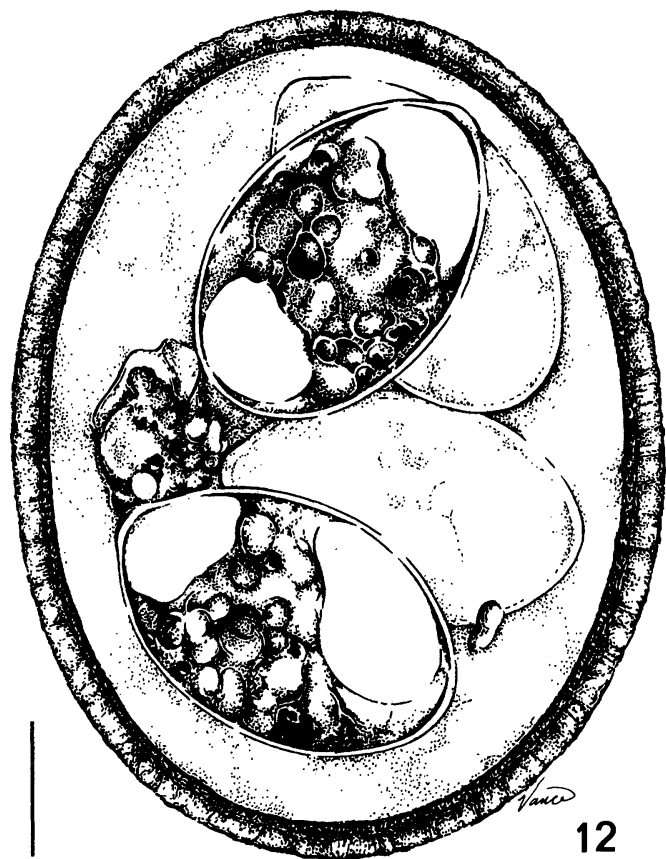

FIGURE 12. Schematic line drawing of sporulated oocyst of Eimeria tomopea. Bar $=5 \mu \mathrm{m}$.
Host: Tomopeas ravus Miller, 1900, Peruvian crevice bat, Louisiana State University Museum of Zoology, LSUMZ 25067 (male), L. J. Barkley \#1667, 7 July 1981 and LSUMZ 25085 (male), J. C. Smith \#707, 15 July 1981.

Locality: Peru: Dpto. Lambayeque; Cerro la Vieja, 7 km S Motupe; ca. $150 \mathrm{~m}$.

Site of infection: Unknown. Oocysts recovered from feces.

Etymology: The specific name is derived from the generic name of the host.

\section{DISCUSSION}

To our knowledge, E. tomopea is the first new coccidian to be described from bats in the last 9 yr. This is surprising because bats are the second most diverse order of mammals in the world, yet only 13 valid eimerians have been described from them. Levine and Ivens (1981) listed 3 additional "species" (E. myotis, E. plecoti and E. viridis), but we are inclined to agree with Wheat (1975) and consider these nomina nuda because their initial descriptions were based on unsporulated oocysts. Since coccidians cannot be assigned to genus without knowledge of their sporulated oocysts it is pure speculation these 3 are eime-

TABLE I. Valid Eimeria spp. described from bats of the world.

\begin{tabular}{|c|c|c|c|}
\hline Host & Locality & Eimeria spp. & Citation \\
\hline \multicolumn{4}{|l|}{ Emballonuridae } \\
\hline $\begin{array}{l}\text { Rhynchonycteris naso } \\
\text { (Brazilian long-nosed bat) }\end{array}$ & British Honduras, Central America & rhynchonycteridis & Lainson (1968) \\
\hline $\begin{array}{l}\text { Taphozous melanopogon } \\
\text { (Tomb bat) }\end{array}$ & Andaman Island, India & andamanensis & Mandal and Nair (1973) \\
\hline $\begin{array}{l}T \text {. nudiventris } \\
\text { (Tomb bat) }\end{array}$ & Egypt, North Africa & dukei & Černá and Ryšavý (1976) \\
\hline \multicolumn{4}{|l|}{ Molossidae } \\
\hline $\begin{array}{l}\text { Eumops trumbulli } \\
\text { (Mastiff bat) }\end{array}$ & Colombia, South America & eumopos & Marinkelle (1968) \\
\hline $\begin{array}{l}\text { Tadarida bemmelini } \\
\text { (Free-tailed bat) }\end{array}$ & Liberia, West Africa & levinei & Bray (1958) \\
\hline $\begin{array}{l}T . \text { limbatus and } T \text {. pumilus } \\
\text { (Free-tailed bats) }\end{array}$ & Uganda, Central Africa & dukei & Lavier (1927) \\
\hline \multicolumn{4}{|l|}{ Rhinolophidae } \\
\hline $\begin{array}{l}\text { Rhinolophus hipposideros } \\
\text { (Lesser horseshoe bat) }\end{array}$ & France, Western Europe & hessei & Lavier (1924) \\
\hline $\begin{array}{l}\text { R. mehelyi } \\
\text { (Horseshoe bat) }\end{array}$ & Azerbaidzhan, Soviet Union & mehelyi & Mussaiev and Gauzer (1971) \\
\hline \multicolumn{4}{|l|}{ Vespertilionidae } \\
\hline $\begin{array}{l}\text { Nyctalus noctula } \\
\text { (Noctule bat) }\end{array}$ & Germany, Eastern Europe & nyctali & Gottschalk (1974) \\
\hline $\begin{array}{l}\text { N. noctule } \\
\text { (Noctule bat) }\end{array}$ & Czechoslovakia, Eastern Europe & vejsovi & Černá (1976) \\
\hline $\begin{array}{l}\text { Pipistrellus subflavus } \\
\text { (Eastern pipistrelle) }\end{array}$ & Alabama, North America & macyi & Wheat (1975) \\
\hline $\begin{array}{l}\text { Tomopeas ravus } \\
\text { (Crevice bat) }\end{array}$ & Peru, South America & tomopea & Present study \\
\hline $\begin{array}{l}\text { Vespertilio murinus } \\
\text { (Frosted bat) }\end{array}$ & Azerbaidzhan, Soviet Union & vespertilii & Mussaiev and Weissov (1961) \\
\hline $\begin{array}{l}V . \text { murinus (=V. kuhlii) } \\
\text { (Frosted bat) }\end{array}$ & Azerbaidzhan, Soviet Union & zakirica & Mussaiev (1967) \\
\hline
\end{tabular}


rians. Thus, even though the term nomen nudum indicates that no description was given, we hold this to be the proper placement for myotis, plecoti and viridis because their sporulated oocysts were never seen. This must represent only a small fraction of the number which actually parasitize these mammals, as Eimeria spp. have been described from only 4 of the 18 (22\%) Recent families of bats, 9 of the $168(5 \%)$ Recent bat genera, and 13 of the $853(1.5 \%)$ living species of bats recognized by Vaughan (1978). Although some bat eimerians may occur in more than 1 host (e.g., E. dukei), we also know that most vertebrate host species harbor 1 or more coccidian species that can be unique to them. If we assume conservatively that there is at least 1 eimerian per bat species, as was done for rodents (Levine and Ivens, 1965), we estimate there may be about 850 species of Eimeria in bats, alone. The number described to date is only $1.5 \%$ of this number.

Tomopeas ravus, the only species in the genus, is known only from the arid and semiarid coastal region of Peru where it can be found from sea level to an elevation of $1,000 \mathrm{~m}$ (Nowak and Paradiso, 1983). This insectivorous species roosts in crevices under the exfoliation of granite boulders and outcroppings. The genus has been placed traditionally in a separate subfamily of the Vespertilionidae because $T$. ravus has physical characteristics that suggest phyletic relationships to both the Vespertilionidae and the Molossidae. Many mammalogists believe it to be an ancient, ancestral type that bridges the gap between these 2 families. However, a recent analysis based largely on biochemical evidence (Barkley, 1984) suggests that $T$. ravus is more closely related to bats of the family Molossidae and should be recognized as a distinct molossid subfamily.

Unfortunately, only 4 species in 4 genera (of the 275 species in 38 genera) of vespertilionids and only 4 species in 2 genera (of the $\cong 80$ species in 12 genera) of molossids have been examined for coccidians. Most bats in these 2, cosmopolitan families are insectivorous. It is interesting to note that the 3 eimerians described from New World vespertilionids and molossids ( $E$. macyi, E. tomopea, E. eumopos) have thick, rough, mammillated oocyst walls, whereas the 6 described from African and Old World vespertilionids and molossids (E. dukei, E. levinei, $E$. nyctali, E. vejsovi, E. vespertilii, E. zakerica) have smooth-walled oocysts. This pattern, if real, may indicate 2, independent eimerian lineages, 1 Old World, 1 New World. Comparative studies of the lineages (e.g., biochemical) may provide important information on host biogeography and phylogeny and host-parasite coevolution.

\section{ACKNOWLEDGMENTS}

This study was supported, in part, by HHS NIH Grant No. RR-08139. We are indebted to J. C. Smith (LSU) for helping to collect bats, to $T$. L. Vance (UNM) for the line drawing and to M. S. Hafner (LSUMZ) for his helpful suggestions when proofing the manuscript.

\section{LITERATURE CITED}

BARKLEY, L. J. 1984. Evolutionary relationships and natural history of Tomopeas ravus (Mammalia: Chiroptera). M.S. Thesis (unpublished). Louisiana State University, Baton Rouge, 100 p.

BRAY, R. S. 1958. On the parasitic protozoa of Liberia. I. Coccidia of some small mammals. Journal of Protozoology 5: 81-83.

ČERNÁ, Ž. 1976. Eimeria vejsovi sp. n. from the bat Nyctalus noctula. Folia Parasitologica (Praha) 23: 187-191.

- AND B. RYŠAvÝ. 1976. Notes on the distribution of Eimeria dukei Lavier, 1927 in African bats. Folia Parasitologica (Praha) 23: 286.

DUSZYNSKI, D. W., G. EASTHAM, AND T. L. YATES. 1982. Eimeria from jumping mice (Zapus spp.): A new species and genetic and geographic features of $Z$. hudsonicus luteus. Journal of Parasitology 68: 1146-1148.

Gottschalk, C. 1974. Eine neue Kokzidienart aus dem Abendsegler (Nyctalus noctula). Angewandte Parasitologie, Jena 15: 3-5.

LAINSON, R. 1968. Parasitological studies in British Honduras. III. Some coccidial parasites of mammals. Annals of Tropical Medicine and Parasitology 62: 252-259.

LAviER, G. 1924. Eimeria hessei n. sp., coccidie intestinale de Rhinolophus hipposideros. Annales de Parasitologie Humaine et Comparée, Paris 2: 335339.

- 1927. Eimeria dukei n. sp., coccidie parasite intestinal de Chéiroptere. Comptes Rendus des Séances de la Société de Biologie et de ses Filiales et Associées, Paris 97: 1707-1709.

Levine, N. D., AND V. Ivens. 1965. The coccidian parasites (Protozoa, Sporozoa) of rodents. Ill. Biol. Monog. \#33. University of Illinois Press, Urbana, p. 186.

-, AND —. 1981. The coccidian parasites (Protozoa, Apicomplexa) of bats. In Parasitological topics: A presentational volume to P. C. C. Garnham, F.R.S., on the occasion of his 80th birthday, E. U. Canning (ed.). Society of Protozoologists, Special Publication No. 1, pp. 170 176.

Mandal, A. K., AND K. N. NaIR. 1973. A new species of coccidium from Taphozous melanopogon Temminik (Mammalia: Chiroptera) from Andaman Islands. Proceedings of the Indian Academy of Sciences, Section B 77: 243-246. 
Marinkelle, C. J. 1968. Eimeria eumopos n. sp. from Colombian bat Eumops trumbulli. Journal of Protozoology 15: 57-58.

MusSAIEV, M. A. 1967. New coccidium species from Vespertilio kuhlii Kuhl. Izvestiǔa Akademii Nauk Azerbaidzhan SSR 5: 37 (In Russian). , AND M. E. GAuzer. 1971. Eimeria mehelyi, a new species of coccidium from Rhinolophus mehelyi. Izvestiǐa Akademii Nauk Azerbaidzhan SSR 2: 94-96 (In Russian).

—, AND A. M. Weissov. 1961. New coccidium species from Vespertilio kuhlii Kuhl. Doklady Akademii Nauk Azerbaidzhan SSR 17: 741-743 (In Russian).

NowaK, R. M., AND J. L. PARAdiso. 1983. Walker's mammals of the world, Vol. 1. Johns Hopkins University Press, Baltimore, 568 p.

Stout, C. A., AND D. W. DuszYNSKI. 1983. Coccidia from kangaroo rats (Dipodomys spp.) in the western United States, Baja California, and northern Mexico with descriptions of Eimeria merriami sp. n. and Isospora sp. Journal of Parasitology 69: 209-214.

Vaughan, T. A. 1978. Mammalogy, 2nd ed. W. B. Saunders Co., Philadelphia, 552 p.

WheAt, B. E. 1975. Eimeria macyi sp. n. (Protozoa: Eimeriidae) from the eastern pipistrelle, Pipistrellus subflavus, from Alabama. Journal of Parasitology 61: 920-922. 